\title{
Freedom of Religion: Recent Developments in the Jurisprudence of the United Kingdom and the European Court of Human Rights ${ }^{1}$
}

\author{
NGTT DEEL 55, NO 1, 2014
}

\section{Hill, Mark QC}

Extraordinary Professor, University of Pretoria

Cardiff University ${ }^{2}$

\begin{abstract}
This paper begins with an overview of the legal landscape in the United Kingdom as it has developed over the past decade or so in relation to the promotion and protection of religious liberty. It analyses several of the more recent cases on the subject and seeks to identify trends and trajectories for future development in the light of the parallel supervisory jurisdiction exercised by the European Court of Human Rights in Strasbourg.
\end{abstract}

1 Paper read on 19 September 2012 at the South African Council for the Promotion and Protection of Religious Rights and Freedoms (Revised for publication, 10 January 2013).

2 Professor Mark Hill QC is a barrister specialising in law and religion. He is Honorary Professor in the Centre for Law and Religion at Cardiff University and sometime Visiting Fellow of Emmanuel College, Cambridge. He has written extensively on religious freedom and discrimination and is Editor of the Ecclesiastical Law Journal. His books include Religious Liberty and Human Rights (2002), Law and Religion in the United Kingdom (2011) and Religion and Discrimination Law in the European Union (2012). He is President of the European Consortium for Church and State Research and sits as a Recorder of the Crown Court on the Midland Circuit and as a judge in the Diocesan courts of the Church of England. 


\section{SETTING THE SCENE}

The early years of the current millennium have seen the development of a sophisticated United Kingdom jurisprudence in both individual and collective religious freedom. ${ }^{3}$ Whilst these rights have long been articulated in instruments of international law (of which English common law has taken substantive cognisance), they have effectively been 'domesticated' through primary legislation emanating from the Westminster Parliament. Historically, for example, fact specific exemptions were given to laws of general application: for instance Sikhs were exempted from the requirement to wear a safety hat on a construction site and from the law relating to the wearing of protective headgear for motor cyclists; ${ }^{4}$ while Jews and Muslims enjoyed exemptions from rules on animal slaughter methods. ${ }^{5}$ Occasionally, special provision has afforded on grounds of religion: for instance it is a defence to charge of having a blade in a public place if the blade is carried 'for religious reasons. ${ }^{6}$ Similarly, section 1 of the Adoption and Children Act 2002 and various other statutes regarding the care of children recognises the right of children to have 'due consideration' given to their 'religious persuasion'. But traditionally these privileges were rare and hard fought. The law provides no special protection for Rastafarians for their use of cannabis on religious grounds ${ }^{7}$ nor would a defence grounded on divine law be sustainable. ${ }^{8}$

However, two recent developments in religion law have led to greater prominence being given to freedom of religion. First, the Human Rights Act 1998 gave 'further effect' to the rights and freedoms guaranteed under the ECHR. Whereas previously the ECHR merely had the status of a treaty obligation under international law, ${ }^{9}$ Convention rights (including freedom of religion under Article 9) are now part

3 See M. Hill \& R. Sandberg, 'Is Nothing Sacred? Clashing Symbols in a Secular World', [2007] PL 488-506 and R. Sandberg, 'The Changing Position of Religious Minorities in English Law: The Legacy of Begum', in Legal Practice and Cultural Diversity, ed. R. Grillo et al. (Aldershot: Ashgate, 2009), 267-282.

4 Employment Act 1989, s. 11; Road Traffic Act 1988, s. 16. For a full account, see S. Poulter, Ethnicity, Law and Human Rights (Oxford: Oxford University Press, 1998), Ch. 8.

5 Welfare of Animals (Slaughter or Killing) Regulations 1995, SI 1995/731, Reg 2.

6 Criminal Justice Act 1988, s. 139.

$7 \quad R$ v. Taylor [2001] EWCA Crim 2263, R v. Andrews [2004] EWCA Crim 947.

8 Blake v. DPP [1993] Crim LR 556.

9 Although individual petition to the European Court in Strasbourg had been permitted since 1966. 
of domestic law, justiciable in domestic courts. Second, the Employment Equality (Religion or Belief) Regulations $2003^{10}$ and the Equality Act 2006 prohibited for the first time discrimination on grounds of religion or belief in employment and the provision of goods and services. These provisions are now to be found in the Equality Act 2010.

Since October 2000, pursuant the provisions of the Human Rights Act 1998, Article 9 of the ECHR are directly justiciable in domestic courts. It provides:

1. Everyone has the right to freedom of thought, conscience and religion; this right includes freedom to change his religion or belief, and freedom, either alone or in community with others and in public or private, to manifest his religion or belief, in worship, teaching, practice and observance.

2. Freedom to manifest one's religion or beliefs shall be subject only to such limitations as are prescribed by law and are necessary in a democratic society in the interests of public safety, for the protection of public order, health or morals, or the protection of the rights and freedoms of others.

This Article provides a positive right to both the freedom of thought, conscience and religion and the manifestation of one's religion or belief. The right to freedom of thought, conscience and religion is absolute. It includes the right to hold a religion or belief and to change it free of State interference. ${ }^{11}$ In contrast, the right to manifest one's religion or belief is limited by Article 9(1) in that the manifestation must be in worship, teaching, practice and observance' and, more importantly, by the possible qualifications in Article 9(2) which permits the State to interfere with the right if the three tests in Article 9(2) are met. The interference must be 'prescribed by law', have one or more of the legitimate aims listed in Article 9(2) and be 'necessary in a democratic society'. Thus, in relation to the right to manifest, litigants need to show that there has been an interference with their manifestation of religion or belief under Article 9(1), the onus then falls on the State to show that this interference is justified under Article 9(2).

\section{THE RISE AND RISE OF LITIGATION}

Most disputes concern the right to manifest. The case law on individual religious freedom under the Human Rights Act 1998 may thus be conceptualised as involving

10 SI 2003/1660.

11 Manoussakis v. Greece (1997) 23 EHRR 387; Metropolitan Church of Bessarabia v. Moldova (2002) 35 EHRR 306. Moscow Branch of the Salvation Army v. Russia [2006] ECtHR (No. 72881/01) (5 Oct. 2006). 
two broad questions: first, whether there is an interference with the right to manifest under Article 9(1) and second, whether that interference with the right to manifest is justified under Article 9(2). It should be noted, however, that in the language of the Human Rights Act 1998 such claims can only be made against public authorities. Unexpectedly, one of the early human rights cases to reach the House of Lords (now reconstituted as the United Kingdom Court of Appeal) concerned the juridic status of the Church of England. ${ }^{12}$

The European Court of Human Rights in Strasbourg has generally taken a formulaic approach to Article 9 cases. The Court invariably begins by stressing the importance of the right, citing the leading case, Kokkinakis $v$. Greece, ${ }^{13}$ which described how 'Freedom of thought, conscience and religion is one of the foundations of a "democratic society" within the meaning of the Convention." ${ }^{14}$ The Kokkinakis justification is twofold, stressing both the social and personal functions of religion. ${ }^{15}$ The European Court of Human Rights permits a 'margin of appreciation' allowing States to differ from each other in relation to their laws and policies to some extent to allow for their different cultures. While previously Strasbourg has spoken of the existence of a wide margin of appreciation in the sphere of morals and religion (especially in relation to attacks on religious convictions), ${ }^{16}$ recent decisions suggest a degree of inconsistency in the deference, which the Strasbourg Court will afford to national legislatures on matters of religion. ${ }^{17}$

The European Court then asks whether there has been an interference with Article 9(1) and if there is whether that interference is justified under Article 9(2). The question of whether there has been interference is often a formality. The question is sometimes expressed as asking whether Article 9 has been engaged. Some cases suggest that these are two separate tests; others suggest that they are the same

12 Aston Cantlow Parochial Church Council v Wallbank [2002] Ch 51.

13 (1994) 17 EHRR 397.

14 Ibid. Note also the extra-judicial opinion of the current President of the European Court of Human Rights: N Bratza, 'The Precious Asset: ${ }^{* * *}$ in M Hill (ed) Religion and Discrimination Law in the European Union (Trier, 2011).

15 P.W. Edge, 'Current Problems in Article 9 of the European Convention on Human Rights', Juridical Review (1996): 42 at 47.

16 See, e.g., Otto Preminger-Institut v. Austria (1995) 19 EHRR 34 at para. 56.

17 See Sahin v. Turkey (2005) 41 EHRR 8 and Lautsi v. Italy [2009] ECtHR (Application No. 30814/06), and in the Grand Chamber, 18 March 2011. 
question expressed differently. This perceived dissonance is likely to be resolved in the forthcoming judgment in Eweida \& Chaplin v United Kingdom. ${ }^{18}$

Strasbourg has employed three 'filtering devices' to exclude claims under the question of interference: the definition of belief, the manifestation/motivation requirement and the specific situation rule. ${ }^{19}$

\section{THE DEFINITION OF BELIEF ${ }^{20}$}

The European Court of Human Rights has taken a liberal approach to the definition of religion. Strasbourg institutions have considered claims concerning scientology, ${ }^{21}$ druidism, ${ }^{22}$ pacifism, ${ }^{23}$ communism, ${ }^{24}$ atheism, ${ }^{25}$ pro-life, ${ }^{26}$ Divine Light Zentrum, ${ }^{27}$ the Moon Sect, ${ }^{28}$ as well as 'splinter' groups within larger traditions, ${ }^{29}$ and have invariably done so without questioning whether the objects of such claims are protected..$^{30}$

The general practice of the Court may be illustrated by its treatment in $X v$. Austria ${ }^{31}$ where the question of whether Nazism was outside the scope of Article 9(1) was

18 Oral argument took place in Strasbourg on 4 September 2012 and the judgment will be delivered on 15 January 2013.

19 R. Sandberg, 'The Changing Position of Religious Minorities in English Law: The Legacy of Begum', in Legal Practice and Cultural Diversity, ed. R. Grillo et al. (Aldershot: Ashgate, 2009), 267-282.

20 See R. Sandberg, 'Defining Religion: Towards An Interdisciplinary Approach', Revista General de Derecho Canonico y Derecho Eclesiâstico del Estado 17 (2008): 1-23.

$21 X$ and Church of Scientology v. Sweden (1978) 16 DR 68.

22 Chappell v. United Kingdom (1987) 53 DR 241.

23 Arrowsmith v. United Kingdom (1978) 19 DR 5.

24 Hazar, Hazar and Acik v. Turkey (1991) 72 DR 200.

25 Angeleni v. Sweden (1986) 51 DR 41.

26 Plattform 'Ärtze für das Leben' v. Austria (1985) 44 DR 65.

27 Omkarananda and the Divine Light Zentrum v. Switzerland (1981) 25 DR 105.

28 Xv. Austria (1981) 26 DR 89.

29 For example, Serifv. Greece (1999) 31 EHRR 561 (Mufti elected by Mosque congregations in opposition to the Mufti appointed by the Government).

30 R. Ahdar \& I. Leigh, Religious Freedom in the Liberal State (Oxford: Oxford University Press, 2005), 124; P.M. Taylor, Freedom of Religion: UN and European Human Rights Law and Practice (Cambridge: Cambridge University Press, 2005), 207.

31 (1963) 13 CD 42. 
not addressed; the Commission simply relied on Article 9(2) to hold that the limitation was justified. Alternatively, the question of definition may be posed but left unanswered: in Chappel $v . U K,{ }^{32}$ for instance, although the existence of Druidism as a religion was questioned, the case was decided purely on the grounds that State restrictions on the celebration of the summer solstice at Stonehenge were justified under Article 9(2).

On occasions, however, Strasbourg will require claimants to prove the existence of the religion in question: in $X v \cdot U K,{ }^{33}$ for example, an application from a prisoner who sought to be registered as a follower of Wicca failed on the grounds that the applicant had 'not mentioned any facts making it possible to establish the existence of the Wicca religion', what Wicca was and why there was a breach. However, 'more recent decisions suggest more generous acknowledgment of non-mainstream religions. ${ }^{\prime}{ }^{34}$

Strasbourg case law tends to revolve around the definition of 'belief', rather than the definition of 'religion'. The term 'belief' is considered in Strasbourg jurisprudence to require a worldview rather than a mere opinion: it was defined in Campbell and Cosans v. United Kingdom, ${ }^{35}$ in reference to Article 2 of the first protocol to the ECHR, as denoting 'views that attain a certain level of cogency, seriousness, cohesion and importance. ${ }^{36}$ However, Strasbourg has only been prepared to use the belief filter in exceptional cases, such as in relation to a strong 'personal motivation' to have your ashes scattered at home, ${ }^{37}$ support of the notion of assisted suicide, ${ }^{38}$ and preferences on the part of prisoners as to prison uniform. ${ }^{39}$

The Strasbourg approach has been replicated at the domestic level. In the House of Lords decision of $R v$. Secretary of State for Education and Employment and others ex parte Williamson, ${ }^{40}$ discussed below, Lord Nicholls noted that the protection

32 (1987) 53 DR 241.

33 (1977) 11 DR 55.

34 M. Taylor, Freedom of Religion: UN and European Human Rights Law and Practice (Cambridge: Cambridge University Press, 2005), 208, citing Omkarananda and the Divine Light Zentrum v. Switzerland (1981) 25 DR 105, X v. Austria (1981) 26 DR 89 and Chappel v. UK (1987) 53 DR 241.

35 EHRR 4 (1982): 293.

36 Paragraph 36.

37 X v. Germany (1981) 24 DR 137.

38 Pretty v. United Kingdom (2002) 35 EHRR 1.

39 McFeely et al v. UK (1980) 20 DR 44.

40 [2005] UKHL 15, [2005] 2 AC 246. 
of 'religion or belief' meant that the question of 'deciding whether a belief is to be characterised as religious ... will seldom, if ever, arise under the European Convention' because it does not matter whether the belief is religious or nonreligious. ${ }^{41}$ Moreover, Lord Nicholls noted that 'Freedom of religion protects the subjective belief of an individual. ${ }^{42}$ Lord Walker of Gestingthorpe, in particular, doubted whether it was right for courts, except in extreme cases, 'to impose an evaluative filter' at the stage of identifying whether there was a belief, 'especially when religious beliefs are involved. ${ }^{43}$

Lord Nicholls held that these requirements applied to 'a non-religious belief, as much as a religious belief'; moreover, a non-religious belief 'must relate to an aspect of human life or behaviour of comparable importance to that normally found with religious beliefs. ${ }^{34}$ For Lord Hope the current jurisprudence did 'not support the proposition that a person's belief in his right to engage in an activity which he carries on for pleasure or recreation [fox hunting in this instance], however fervent or passionate, can be equated with beliefs of the kind that are protected by Article 9' since that would make it difficult to 'set any limits on the range of beliefs that would be opened up for protection. ${ }^{45}$

Generally, however, domestic courts have not relied upon the definition of belief as a filter in their interpretation of Article $9 .{ }^{46}$ This is shown by two cases concerning religious drug use: ${ }^{47}$ in $R v$. Taylor ${ }^{48}$ and $R v$. Andrews, ${ }^{49}$ cases concerning respectively the possession and importing of cannabis by Rastafarians, the Court of Appeal held that anti-drug laws could be justified under Article 9(2). It was assumed without comment that Rastafarianism was a religion and that drug taking was capable being a manifestation of that religion under Article 9(1).

41 Paragraph 24.

42 Paragraph 22.

43 Paragraph 57.

44 At para. 24.

45 Whaley v. Lord Advocate [2007] UKHL 53 at para. 18.

46 Compare this with the case law on religious discrimination.

47 See P.W. Edge, 'Religious Drug Use in England, South Africa and the United States of America', Religion \& Human Rights 1, no. 2 (2006): 165-177; M Gibson, 'Rastafari and Cannabis: Framing a Criminal Law Exception’ Ecc LJ (2010) 12: 324.

48 [2001] EWCA Crim 2263.

49 [2004] EWCA Crim 947. 
The High Court decision in $R$ (on the Application of Ghai) v. Newcastle City Council ${ }^{50}$ suggested however that Article 9 only affords protection to activities that are at the core of religious life. Hindus and Sikhs who sought to have cremations on open-air funeral pyres brought the case. Noting the Secretary of State's contention 'that the weight to be given to religious rights depends on how close the subject matter is to the core of the religion's values or organisation', and rejecting the submission 'that the determination of the core content of the Hindu religion is not a matter for the court', Cranston J held that Hindu beliefs about an open air funeral pyre satisfied what he styled 'the Williamson thresholds': they had 'the requisite degree of seriousness and importance' and were 'concerned with central rather than peripheral matters. ${ }^{51}$ In relation to Hindu claims the High Court held that there had been interference with Article 9(1) but that this interference was justified under Article 9(2). In contrast, Cranston J held that 'Article 9 accords no protection to the Sikh tradition of using open air funeral pyres; because it was conceded that their use was 'simply a matter of tradition' and 'not a matter of dogma and belief.'52 The pending ruling of the European Court of Human Rights in Eweida \& Chaplin $v$ UK is likely to address the degree to which a practice must be doctrinally mandated before it amounts to a manifestation of religious belief.

\section{MANIFESTATION}

The second filter used in relation to Article 9(1) is the manifestation requirement, which requires that the particular practice is one used by a person to manifest his or her religion or belief as opposed to being merely motivated by it. ${ }^{53}$ This rule has been criticised on the basis that the presence or absence of religious motivation may serve as a good indicator of whether a belief should be protected and that a rigid adherence to the manifestation requirement 'would seem to discriminate against religions without an established cultural base in European States' whose devotions

50 [2009] EWHC (Admin) 978.

51 Paragraph 101.

52 Paragraph 102. Although the High Court's decision was later reversed on appeal ([2010] EWCA Civ 59), the Court of Appeal held that the accommodation of the claimant's wishes would not in fact necessarily infringe the legislation relating to cremation. The appellate judgment, therefore, did not focus upon the Art. 9 claim.

53 Arrowsmith v. United Kingdom (1981) 3 EHRR 218. 
'take different forms, such as sexual intercourse, ritual violence, or refusal to pay taxes to a centralised state hostile to their beliefs. ${ }^{54}$

It is not surprising, therefore, that this filter is not always employed by the court. ${ }^{55}$ At Strasbourg, the test has often been rephrased as requiring, for example, that the action is 'intimately linked' to the claimant's religion or belief, ${ }^{56}$ or whether the actions 'give expression' to it. ${ }^{57}$ These requirements are seemingly less strict. At first, it appeared that the domestic courts were to follow Strasbourg in adopting a relaxed interpretation of this requirement.

In $R v$. Secretary of State for Education and Employment and others ex parte Williamson, ${ }^{58}$ head teachers, teachers and parents of children at four independent schools where discipline was enforced by the use of mild corporal punishment alleged, inter alia, that the new ban on corporal punishment in schools ${ }^{59}$ breached Article 9 as being incompatible with their belief that physical punishment was part of the duty of education in a Christian context. ${ }^{60}$ While the Court of Appeal dismissed the claim, holding that the infliction of corporal punishment was not a manifestation for the purposes of Article 9, ${ }^{61}$ the House of Lords dealt with Article 9 'overtly and comprehensively, paying careful attention to freedom of religion and belief' ${ }^{62}$ The House of Lords held that although there had been interference with the applicant's Article 9 rights, this was justified under Article 9(2) as being prescribed by law, ${ }^{63}$ necessary in a democratic society for the protection of the rights and freedoms of

54 P.W. Edge, 'Current Problems in Article 9 of the European Convention on Human Rights' Juridical Review (1996): 42 at 45-47.

55 S. Knights, Freedom of Religion, Minorities and the Law (Oxford University Press, Oxford 2007), 44; R. Sandberg, 'The Changing Position of Religious Minorities in English Law: The Legacy of Begum', in Legal Practice and Cultural Diversity, ed. R. Grillo et al. (Aldershot: Ashgate, 2009).

56 C v. UK (1983) 37 DR 142, 144; Hasan and Chaush v. Bulgaria (2002) 34 EHRR 55.

57 Knudsen v. Norway (1985) 42 DR 247.

58 [2005] UKHL 15, [2005] 2 AC 246.

59 Education Act 1998 s. 548 (as amended in 1998).

60 See, for instance, Proverbs 13:24.

61 [2002] EWCA Civ 1926.

62 S. Langlaude, 'Flogging Children with Religion: A Comment on the House of Lords', Decision in Williamson' Ecc LJ 8 (2006): 335, 345.

63 Since the ban was 'prescribed by primary legislation in clear terms', Lord Nicholls at para. 48. 
others ${ }^{64}$ and as having a legitimate aim to protect children as a vulnerable group and promote their well-being. ${ }^{65}$

Although Lord Nicholls did note the motivation requirement, stating that 'Article 9 does not "in all cases" guarantee the right to behave in public in a way "dictated by a belief "', ${ }^{66}$ he held that this should not exclude the claim. He further noted that if 'the belief takes the form of a perceived obligation to act in a specific way, then, in principle, doing that act pursuant to that belief is itself a manifestation of that belief in practice' and that 'in such cases the act is "intimately linked" to the belief' ${ }^{67}$ However, he added this did not mean 'that a perceived obligation is a prerequisite to manifestation of a belief in practice. ${ }^{68}$ That a belief was obligatory was simply good evidence that the exercise of that belief was manifestation protected by Article 9; it was not the case that a belief had to be obligatory to be protected by Article 9 .

A later domestic decision, albeit by a lower court, seemingly misinterpreted Lord Nicholls's statement as suggesting that a belief must be obligatory to be protected by Article 9. ${ }^{69}$ In $R$ (on the Application of Playfoot (A Child)) v. Millais School Governing Body $y^{70}$ an application for judicial review of a decision by a school to prevent a schoolgirl from wearing a 'purity' ring on grounds of Articles 9 and 14 of the ECHR was refused by the High Court on the question of interference: Michael Supperstone QC, sitting as a High Court judge, held that Article 9 was not engaged since, although the claimant held a 'religious belief', in that she had made a decision to remain celibate until marriage because she was a Christian, the wearing of the ring was not 'intimately linked' to the belief in chastity before marriage because Playfoot was under no obligation, by reason of her faith, to wear the ring.

In deciding this, the judge correctly cited Lord Nicholls in Williamson as stating that if 'the belief takes the form of a perceived obligation to act in a specific way, then, in principle, doing that act pursuant to that belief is itself a manifestation of that belief in practice' but incorrectly said that this meant that the reverse was also true: if there

64 Lord Nicholls at para. 49.

65 Lord Nicholls at para. 49. The means chosen to achieve that aim were appropriate and proportionate: Lord Nicholls at para. 50.

66 Paragraph 30.

67 At paras 32-33.

68 At paras 32-33.

69 R. Sandberg, 'Controversial Recent Claims to Religious Liberty', LQR 124 (2008): 213.

70 [2007] EWHC Admin 1698. 
was no such obligation then the act cannot be a manifestation of that belief. ${ }^{71}$ This is the reverse of what Lord Nicholls stated. It is noteworthy that cases concerning religious discrimination law have not adopted the Playfoot position. In $R$ (on the application of Watkins-Singh) v. The Governing Body of Aberdare Girls' High School, ${ }^{72}$ a schoolgirl who was an observant though non-initiated Sikh sought to wear her Kara bracelet to school. Silber J heard expert evidence that although the Kara was often worn it was only compulsory in the case of initiated Sikhs. Nevertheless, it was held that this was not fatal to the claim of religious discrimination. Silber J stated that the needed disadvantage would occur - but would not only occur - where a pupil is forbidden from wearing an item where 'that person genuinely believed for reasonable grounds that wearing this item was a matter of exceptional importance to his or her racial identity or his or her religious belief' and where 'the wearing of the item can be shown objectively to be of exceptional importance to his or her religion or race, even if the wearing of the article is not an actual requirement of that person's religion or race. ${ }^{73}$ This approach, though related to religious discrimination law, is more in line with the most recent Strasbourg jurisprudence on the manifestation/ motivation requirement than the decision in Playfoot.

\section{THE SPECIFIC SITUATION RULE}

The third 'filtering device' may be styled the specific situation rule: it recognises that a person's Article 9 rights may be influenced by the particular situation of the individual claiming that freedom. This principle is not of universal application: it only applies where someone voluntarily submitted to a particular regime. Strasbourg has recognised that the application of this rule in specific situations such as in relation to a detained person, ${ }^{74}$ a person who voluntarily submits to military service, ${ }^{75}$ a person who voluntarily enter into a contract of employment ${ }^{76}$ and those who voluntarily enrol at a university. ${ }^{77}$

71 Paragraph 23.

72 [2008] EWHC (Admin) 1865.

73 Paragraphs 56-57.

$74 X$ v. United Kingdom (1974) 1 D\&R at 41-42.

75 Kalaçv. Turkey (1997) 27 EHRR 552.

76 Stedman v. United Kingdom (1997) 5 EHRLR 544; Ahmad v. United Kingdom (1981) 4 EHRR 126.

77 Karaduman v. Turkey (1993) 74 DR 93. 
However, in Jewish Liturgical Association Cha'are Shalom Ve Tsedek v. France ${ }^{78}$ Strasbourg went a little further by imposing an 'impossibility test': the Court commented that an 'alternative means of accommodating religious beliefs had ... to be "impossible" before a claim of interference under Article 9 could succeed.' This broader approach has not been followed in subsequent Strasbourg cases. ${ }^{79}$ For instance, ${ }^{80}$ in Thlimmenos $v$. Greece ${ }^{81}$ the Court simply accepted that the 'set of facts' complained of fell 'within the ambit' of Article 9 since it was 'prompted' by the claimant's religion or belief. ${ }^{82}$ The Court noted that it did 'not find it necessary' to examine whether the facts 'amounted to interference with his rights under Article 9(1) ${ }^{83}$ In Sahin v. Turkey, ${ }^{84}$ concerning a university regulation banning a student from wearing a headscarf at enrolment, lectures and examinations, although the specific situation rule was referred to by the Court, ${ }^{85}$ the Court proceeded 'on the assumption that the regulations in issue, which placed restrictions of place and manner on the right to wear the Islamic headscarf in universities, constituted an interference with the applicant's right to manifest her religion. ${ }^{36}$

The earlier decisions of the United Kingdom courts recognised the specific situation rule but echoed the latter Strasbourg jurisprudence in noting its limited scope and refrained from enthusiastically applying the rule. This was epitomised by the Court of Appeal decision in Copsey v. WBB Devon Clays Ltd ${ }^{87}$ concerning an employee dismissed after he had refused to agree to the introduction of a rotating shift procedure which included some Sunday working. Although Court of Appeal dismissed the employee's appeal on the basis of domestic employment law, the

$78 \quad$ (2000) 9 BHRC 27.

79 S. Knights, Freedom of Religion, Minorities and the Law (Oxford: Oxford University Press, 2007), 44; R. Sandberg, 'The Changing Position of Religious Minorities in English Law: The Legacy of Begum', in Legal Practice and Cultural Diversity, ed. R. Grillo et al. (Aldershot: Ashgate, 2009), 267.

80 The Court has not applied the specific situation rule in the case of a non-religious claimant who has voluntarily submitted to a religious situation. See Lautsi v. Italy [2009] ECtHR (Application No. 30814/06).

81 (2001) 31 EHRR 15.

82 Paragraph 42.

83 Paragraph 43.

84 (2005) 41 EHRR 8.

85 Paragraph 66.

86 Paragraph 71.

87 [2005] EWCA Civ 932. 
judges were extremely critical of Article 9 and the Strasbourg specific situation rule questioning whether it enhanced the protection afforded by domestic law.

Mummery LJ declared that if there had been no authority on the specific situation rule, he would have thought it necessary to examine the arguments under Article 9(2). He made several criticisms of the specific situation rule noting that it amounted to 'repeated assertions unsupported by the evidence or reasoning that would normally accompany a judicial ruling' which 'are difficult to square with the supposed fundamental character of the rights' and noted that Strasbourg cases alleging breaches of other Articles and recent domestic cases on Article 9 had not followed it. ${ }^{88}$ Similarly, Neuberger LJ described the 'specific situation' case law as 'arguably surprising and the reasoning hard to follow' and concluded that this meant that Article 9 did not take the matter further than domestic law. ${ }^{89}$ Rix LJ also suggested that the English law on unfair dismissal was more generous than the rights granted by Strasbourg and even sought to distinguish the rule holding that held that the 'specific situation' rule did not extend to the situation where an employer sought to vary the employee's working hours. ${ }^{90}$ Although the employee's case was dismissed, the Court of Appeal displayed considerable hostility towards the specific situation rule and sought to narrow its ambit.

The House of Lords decision in Williamson also recognised the existence of the specific situation rule, but did not apply it to the facts of the case. As Lord Nicholls noted, 'What constitutes interference depends on all the circumstances of the case, including the extent to which in the circumstances an individual can reasonably expect to be at liberty to manifest his beliefs in practice', meaning that an individual 'may need to take his specific situation into account.9' This rule did not apply on the facts since there was 'no comparable special feature affecting the position of the claimant parents. ${ }^{\prime 2}$ In particular, Lord Nicholls rejected the submission of the Secretary of State that there had been no interference since section 548 (which forbade corporal punishment) 'left open to the parents several adequate, alternative courses of action' such as home education, ${ }^{93}$ as being unrealistic. ${ }^{94}$

\footnotetext{
88 Paragraph 35.

89 Paragraph 91.

90 Paragraph 65.

91 At para. 38.

92 At para. 39.

93 At para. 40.

94 At para. 41.
} 
The opposite approach has, however, been employed in the some subsequent domestic decisions on Article 9: in response to cases on religious dress, judges have relied upon the specific situation rule and have applied the rule outside its original contractual setting meaning that English law has now effectively adopted the 'impossibility' test elucidated in the Jewish Liturgical case. ${ }^{95}$ In $R$ (on the application of Begum) v. Headteacher and Governors of Denbigh High Schoo ${ }^{96}$ the claimant contended that her school's ban on wearing a jilbab was a breach of her Article 9 rights. The House of Lords held unanimously that there was no such breach, with the majority (Lords Bingham of Cornhill, Hoffmann and Scott of Foscote) holding that there had been no interference with the applicant's rights under Article 9(1) because of the specific situation rule. Lord Bingham stated that:

"The Strasbourg institutions have not been at all ready to find an interference with the right to manifest religious belief in practice or observance where a person has voluntarily accepted an employment or role which does not accommodate that practice or observance and there are other means open to the person to practise or observe his or her religion without undue hardship or inconvenience." ${ }^{97}$

He concluded that the Strasbourg case law indicated that interference is not easily established. ${ }^{98} \mathrm{He}$ then applied the 'specific situation' rule to the case without explanation as to why it ought to be applied to school pupils despite the lack of contractual relationship between school and pupil.

The new version of the specific situation rule as advanced in Begum was applied by the High Court in $R$ (on the application of X) v. Y School. ${ }^{99}$ Silber J considered the Begum precedent to be 'an insuperable barrier' to a claim for judicial review by a schoolgirl who wished to wear a niqab veil while she was being taught by male teachers or was likely to be seen by men. Quoting Lord Bingham, Silber J found no interference with the claimant's rights under Article 9 and interpreted Lord Bingham's elucidation of the specific situation rule in Begum as meaning that there would be no interference either where a person has voluntarily accepted an employment or role that does not accommodate that practice or observance or where there are other means open to practise or observe that religion without undue hardship or inconvenience.

95 See M. Hill \& R. Sandberg, 'Is Nothing Sacred? Clashing Symbols in a Secular World' [2007] PL 488-506.

96 [2006] UKHL 15.

97 At para. 23.

98 At para. 24.

99 [2006] EWHC (Admin) 298. 
Similarly in Playfoot, the judge noted that if he had found that the purity ring was a manifestation of religion then, there would have been no interference with Article 9 since the claimant had voluntarily accepted the school's uniform policy and there were other means open to her to practice her belief without undue hardship or inconvenience. The awaited decision of the Strasbourg case in Eweida, Chaplin, Ladele and McFarlane will consider whether they're a meaningful jurisprudential future for the specific situation rule. ${ }^{100}$

\section{JUSTIFICATION}

In Strasbourg jurisprudence the focus invariably shifts from the question of interference under Article 9(1) to the Article 9(2) qualifications, which are used to determine whether the interference (admitted or proved) by the State was justified. The same is also true of domestic decisions, though for the reasons discussed above, in most cases the consideration of Article 9(2) by a domestic court is often obiter, the Court having rejected the claim on the question of interference under Article 9(1). The vast majority of decisions address the three tests laid out in Article 9(2) applying them sequentially: to be justified the interference must be 'prescribed by law', have a 'legitimate aim' and be 'necessary in a democratic society'.

\section{(a) Prescribed by Law}

This first test requires that the interference must have some basis in domestic law. Strasbourg has defined 'law' broadly to include statutory law and 'written law' encompassing enactments of lower rank than statutes, ${ }^{101}$ regulatory measures taken by professional regulatory bodies under independent rule-making powers delegated to them by Parliament, ${ }^{102}$ as well as judge-made law and 'unwritten law'. ${ }^{103}$ Implicit within this test is the requirement that the interference complies with European rule of law standards. ${ }^{104}$ This test has not proved problematic for the domestic judiciary: for instance, the House of Lords has held that both a rule 'prescribed by primary

100 The judgment is due to be delivered on 15 January 2013 and can be viewed thereafter on the website of the European Court of Human Rights.

101 De Wilde, Ooms and Versyp v. Belgium (1979-80) 1 EHRR 373.

102 Barthold v. Germany (1985) 7 EHRR 383.

103 The Sunday Times v. United Kingdom (No.1) (1979-80) 2 EHRR 245.

104 C. Evans, Freedom of Religion under the European Convention on Human Rights (Oxford: Oxford University Press, 2002), 138. 
legislation in clear terms ${ }^{105}$ and a school uniform policy ${ }^{106}$ was prescribed by law. In relation to the latter, emphasis was given to the fact that schools and their governors were permitted under statutory authority to make rules on uniform and those rules had been very clearly communicated to those affected by them. ${ }^{107}$

\section{(b) Legitimate Aim}

The second test is that the interference fulfils one of the (sometimes-overlapping) aims listed in Article 9(2). ${ }^{108}$ At Strasbourg, this requirement is often a formality: Taylor has noted that the margin of appreciation adopted by European institutions means that they 'tend to accept rather than challenge the aim claimed by the State, and accordingly pass over this precondition with little detailed analysis. ${ }^{\prime}{ }^{109}$ The same appears to be true of United Kingdom courts. Although in most cases the legitimate aim is protecting the rights and freedoms of others, ${ }^{110}$ a wide range of legitimate aims have been cited by courts. The question of how narrow a legitimate aim may be was addressed by the Court of Appeal in $R$ (on the Application of Swami Suryananda) v. Welsh Ministers ${ }^{111}$ concerning the decision by the Welsh Assembly Government to order the slaughter of Shambo, a bullock at the claimant's Hindu temple, who had tested positive for the bacterium that causes bovine tuberculosis (TB). ${ }^{112}$ The claimant applied for judicial review, contesting that, since the sacredness of life was a cornerstone of Hindu beliefs and bovines played an important part in Hinduism, the decision breached his rights under Article 9 ECHR. The High Court ${ }^{113}$ granted the application for judicial review and quashed the decision by the Welsh Ministers, holding that the Welsh Assembly Government had defined this legitimate object too narrowly to be a proper public interest objective for the purposes of Article 9(2): the

$105 R$ v. Secretary of State for Education and Employment and others ex parte Williamson [2005] UKHL 15, [2005] 2 AC 246.

106 This was accepted by all of the appellate committee in Begum.

107 Lord Bingham at para. 26.

108 C. Evans, Freedom of Religion under the European Convention on Human Rights (Oxford: Oxford University Press, 2002).

109 P.M. Taylor, Freedom of Religion: UN and European Human Rights Law and Practice (Cambridge: Cambridge University Press, 2005), 301-302.

110 See Begum, Lord Bingham at para. 26, Lord Hoffmann at 58 and Baroness Hale at 94.

111 [2007] EWCA Civ 893.

112 See R. Sandberg, 'Controversial Recent Claims to Religious Liberty', LQR 124 (2008): 213.

113 [2007] EWHC (Admin) 1736. 
elimination of any risk of a particular animal transmitting TB may be appropriate in the pursuit of some wider public health objective but cannot be a public health objective in itself. The Court of Appeal unanimously allowed the appeal and on the question of the legitimate aim holding that although there is a risk that an objective may be framed so narrowly that it becomes coincident with the results sought; in the instant case the Welsh Ministers had a public health objective - the eradication or at least control of bovine tuberculosis and so the Minister was entitled to make the decision she did.

\section{(c) Necessary in a democratic society}

The third test has been the subject of clarification by Strasbourg. It is understood that the requirement that the interference be necessary in a democratic society requires two tests to be met: the interference must correspond to a 'pressing social need' and it must be 'proportionate to the legitimate aim pursued.' ${ }^{114}$ This requires a 'balancing exercise' whereby the court asks 'whether the interference with the right is more extensive than is justified by the legitimate aim.' ${ }^{115}$ Since 'the notion of proportionality will always contain some subjective element and depend significantly on the context, ${ }^{116}$ it is not surprising that different judges have taken differing approaches to this test. In Begum, for instance, the House of Lords conceptualised the question largely in terms of proportionality, giving scant attention to identifying a pressing social need. ${ }^{117}$ Lady Hale concluded that the school's uniform policy was a thoughtful and proportionate response to reconciling the complexities of the situation. This is demonstrated by the fact that girls have subsequently expressed their concern that if the jilbab were to be allowed they would face pressure to adopt it even though they do not wish to do so. ${ }^{118}$

114 Serifv. Greece (2001) 31 EHRR 20.

115 D. Feldman, Civil Liberties and Human Rights in England and Wales, 2nd edn (Oxford: Oxford University Press, 2002), 57.

116 C. Evans, Freedom of Religion under the European Convention on Human Rights (Oxford: Oxford University Press, 2002), 145.

117 Lord Bingham para. 26, Lady Hale at para. 94.

118 Paragraph 98. Drawing upon Sahin, Lord Bingham concluded that that the interference with the Art. 9(1) right was proportionate since the school 'had taken immense pains to devise a uniform policy which respected Muslim beliefs but did so in an inclusive, unthreatening and uncompetitive way': para. 34 . 


\section{NEW TRAJECTORIES}

What movements can be discerned in more recent United Kingdom cases and are they consistent with Strasbourg jurisprudence? A significant High Court decision in $R$ on the Application of Bashir $v$ The Independent Adjudicator and HMP Ryehull and the Secretary of State for Justice. ${ }^{119}$ The case concerned a prisoner, was charged with failing to obey a lawful order contrary to Rule 51(22) of the Prison Rules 1999 when he failed to provide an adequate urine sample as part of the prison's mandatory drug testing policy. Although the claimant was a devout Muslim who was fasting as part of his religious preparation prior to a Court of Appeal appearance, the Independent Adjudicator had found the claimant guilty of failing to obey a lawful order. The Prison Service Order PSO 3601 on 'Mandatory Drug Testing' outlined different rules that could be applied in relation to the collection of urine samples during 'religious festivals, which involve total fasting' but these did not apply in the present case since it was not a religious festival. The Adjudicator concluded that although there is nothing to stop individuals fasting on other days, they must live with bear the consequences of so doing. ${ }^{120}$

At the High court, this adjudication was challenged as being contrary to Article 9 and was quashed. The judge held that the circumstances required the Adjudicator to consider the applicability of Article 9, examining whether Article 9 was engaged, whether there was an interference with these rights and whether that interference had been justified under Article 9 (2). Simply considering applicability of the religious festival exception was 'a wrong approach.' ${ }^{121}$ The decision was quashed since it could not be demonstrated that a reasonable Adjudicator correctly directing himself would have necessarily come to a similar conclusion as that reached by the Adjudicator in this case. The judge held that Article 9 was engaged because there was 'no real doubt' that the claimant's fast was intimately linked to his religious belief. ${ }^{122}$

"Although the Defendant relies on the fact that the fast being undertaken by the Claimant was not obligatory but voluntary, I reject that as a relevant consideration for present purposes. There is nothing within Article 9 that requires there to be a perceived, much less an objectively demonstrable, obligation for the manifestation of religious belief to be protectable. Lord Nicholls does not suggest that to be so in Paragraph 32 of his Opinion in

119 [2011] EWHC 1108 (Admin).

120 At para 6.

121 At para 16.

122 At para 20. 
Williamson. Indeed, he says quite the opposite in paragraph 33. On the evidence before the Adjudicator the Claimant's fasting was a manifestation that was motivated or inspired by a religion and was not unreasonable and thus satisfied the relevant threshold requirements for Article 9 to be engaged." ${ }^{23}$

This corrects the misinterpretation of Williamson in Playfoot (and also seems contrary to the spirit of Eweida). It also dismantles the distinction drawn in Arrowsmith between manifestations and motivations and seemingly introduces a new reasonableness test (which if applied objectively would be contrary to Lord Nicholl's insistence in Williamson that 'freedom of religion protects the subjective belief of an individual.' ${ }^{124}$

The judge gave short shrift to the Adjudicator's argument that relied upon Lord Bingham's specific situation rule in Begum on the basis that:

"None of the authorities that are [sic] considered by Lord Bingham in that paragraph concern the position of prisoners. Although it was argued on behalf of the Defendant that the Claimant should be treated as having voluntarily accepted the restrictions implicit in a prison environment by committing the offences for which he had been convicted, I am not convinced that is a correct analysis." 125

\section{At para 21.}

$124 R v$ Secretary of State for Education and Employment and others, ex parte Williamson [2005] UKHL 15, at para 22. The judge did not take a purely subjective approach. In reaching his conclusion that the fasting was a manifestation of his religion or belief, he placed weight upon the fact that the claimant had been advised by an Imam to embark on a three day fast and that the prison Imam had given evidence that 'personal fasting was a recognised tenet of Islam and there was an apparently objectively good reason for the Claimant wanting to undertake such a fast': as spiritual preparation for his impending appearance at the Court of Appeal (para 20). The judge's reliance on the views of the Imam, his reference to the need for an 'objectively good reason' for the manifestation of religion and his assumption of competency to assert what is and what is not 'a recognised tenet of Islam' are all questionable. The judge was seeking to determine the genuineness of Bashir's claim contrary to the principles laid out in Williamson, although there is some degree of contradiction since in paragraph 18 the judge held that 'The Officer's evidence is of no value in determining the genuineness of the claimant's belief as to whether the fast could be broken'.

125 Para 22. 
He pointed out that 'the only European Court of Human Rights (ECtHR) authority cited by either party that concerned a prisoner was Jakobski $v$ Poland ${ }^{126}$. This may be the case but there are other clear examples of the specific situation rule being applied in the prison context, such as in $X v$ United Kingdom ${ }^{127}$. However, if the specific situation rule does not apply in a prison setting where the claimant has broken the social contract with society, it is arguable that it should not apply to other situations outside those regulated by a contract of employment. This seems to adopt a much narrower interpretation of the principle than is seen in the run of other cases. The judge adopted a much more generous general approach to the question of interference:

"In my judgment the question of whether there has been interference becomes essentially a factual one. Having accepted that for the Claimant to embark upon and maintain a three day fast which he genuinely believed could not be broken was a manifestation of his religious beliefs, it necessarily follows that to require him to provide a sample of urine which he was not able to provide without breaking his fast was an interference with the Claimant's Article 9 rights. Thus, I conclude that the sole issue that arises in the circumstances of this case is ... whether the interference is prescribed by law, has one of the legitimate aims identified in Article 9(2) and is proportionate." 128

This shifts the focus from the question of interference under Article 9(1) onto the question of justification under Article 9(2). The judge concluded that this interference was not justified under Article 9(2) in that although the drug testing policy was 'prescribed by law' and fulfilled at least one of the legitimate aims laid out in the Article, it was not proportionate. ${ }^{129}$ There was no evidence before the Adjudicator concerning the cost or inconvenience of making appropriate adjustments in the particular circumstances that arose. ${ }^{130}$ As the judge concluded: 'There was no evidence before the Adjudicator which enabled him to conclude (as apparently he did) that it was proportionate to require all Muslim prisoners engaged in personal fasting to break that fast as and when required to do so for the purposes of providing a [sample] regardless of the circumstances. ${ }^{131}$ He stressed that his judgment was not

126 Application Number: 18429/06 (7 December 2011).

127 (1974) 1 D\& R 41.

128 At para 23.

129 At para 24.

130 At para 28.

131 At para 29. 
intended to have any effect on the lawfulness of the drug testing policy and that his conclusions were 'case specific and fact sensitive. ${ }^{132}$

This can be shown by the treatment of the specific situation rule in National Secular Society $v$ Bideford Town Council ${ }^{133}$. Although the Article 9 claim would have been unsuccessful (on the assumption that the saying of prayers at the commencement of a meeting of a local authority was lawful), Ouselely J stated that there had been no voluntary submission in this case:

"I do not accept Mr Dingemans' argument that because Mr Bone had chosen to stand for election to a Council which had this practice, he had accepted the burden of its continuance until he could change it by democratic vote. ... This fails to recognise that becoming an elected representative is more than just a job for a politician; it is the fundamental right of the electorate to choose whom they wish to represent them in the body to which they have elected him. If it is an interference with the right not to hold religious views, or if it is an unnecessary or unjustifiable interference or act of discrimination, this cannot be treated as a case of voluntary submission." 134

This would suggest that there remains some limits to the specific situation rule can be applied. This tendency not to rely on the notion of contracting-out can be further shown by recent litigation concerning the 'Occupy Movement', which formed a camp in St Paul's Cathedral Churchyard, The Mayor, Commonality and Citizens of London $v$ Tammy Samede. ${ }^{135}$ One argument was that allowing the camp to remain breached the Article 9 rights of those concerned with St Paul's Cathedral. Although the Cathedral was not a party to the case, this was one of the reasons put forward in the argument that the interference with the protestors' Article 10 and 11 rights was not justified. In the High Court ${ }^{136}$ Lindblom J held that the City had undoubtedly established that there was a pressing social need to not to permit the camp to remain at the Cathedral and that this was in part because of the effect the occupation had on the Article 9 rights of the Cathedral:

132 At para 34; further, '[i]n any subsequent case where lawfulness is challenged on Article 9 grounds, each of the three questions I have identified above will have to be asked. The answers that will be arrived at will depend entirely upon the evidence before the Adjudicator before whom the issue is raised'.

133 [2012] EWHC 175 (Admin).

134 Para 75.

135 [2012] EWHC 34 (QB); [2012] EWCA Civ 160.

136 [2012] EWHC 34 (QB). 
"I am convinced that the effects of Occupy's protest camp in St Paul's churchyard have been such as to interfere seriously with the rights, under Article 9 of the Convention, of those who desire to worship in the cathedral. ... During the camp's presence, and, in my view, largely if not totally as a result of its presence, there has been a drop of about two fifths in the numbers of those worshipping in the cathedral. About the same fraction has been lost in the number of visitors, an important source of funds for the upkeep of the building and for its ministry. .... Together, and without more, [this] would, in my view, justify the granting of relief. I have no hesitation in reaching that conclusion even though the Church is not itself a party in the City's claim and has not issued proceedings of its own."137

Like in Bashir, the specific situation rule was held not to apply:

"To say that those who are put off attending services in the cathedral can go and worship elsewhere, with more than 450 other churches in the diocese of London to choose from, misses the point. It is to misunderstand the nature of the right in Article 9, which is not that one is entitled to worship only where the activities of others make it comfortable or convenient to do so, or where one is made to go by others in the exercise of their own Convention rights, but where one chooses to worship in accordance with the law."138

In the Court of Appeal, ${ }^{139}$ the Master of the Rolls upheld the decision of the High Court, holding that there was 'no chance that any of the criticisms raised by each of the defendants, or even all of those criticisms taken together, could persuade an appellate court that [the first instance judge's] decision was wrong. ${ }^{140}$ In relation to the Article 9 point, the appellants contended that

"The Judge ought not to have found ... that there was any interference with the rights of those who wished to worship at St Paul's Cathedral, given that (a) no worshipper gave evidence, and (b) the Occupy Movement stands for the same values as the Church of England." ${ }^{141}$

The Master of the Rolls held that neither of these arguments were tenable because:

137 Para 162

138 Para 162

139 [2012] EWCA Civ 160.

140 Para 60.

141 Para 34. 
"As to (a), the Judge was plainly entitled to reach the conclusion that he arrived at. He had figures, which showed a very significant reduction in worshippers at, and visitors to, the Cathedral since the Camp had arrived, and evidence of opinion from the Cathedral Registrar that the reduction was caused by the Camp. While there were some other possible explanations for the reduction, the Judge was, to put it at its lowest, entitled to reach the view that he did. As to point (b), it is true that some prominent members of the Church of England have expressed support for the Camp, but that is no answer to the Judge's concern about the interference by the Camp with the access of people who wish to worship in the Cathedral." ${ }^{142}$

The cases of Bashir, Bideford and Samede therefore show a tendency not to rely on the notion of contracting-out to dismiss Article 9 claims. Although the Article 9 arguments were not successful in all these cases, the religious rights dimension seems to be considered in a much more mature and nuanced way. This is true of recent cases, which have relied upon the notion of contracting-out but have done so in the context of the Article 9(2) question of justification rather than the Article 9(1) question of interference. The decision in National Secular Society $v$ Bideford Town Council ${ }^{143}$ provides some evidence of this. Although, Ouselely J stated that there had been no voluntary submission, he nevertheless considered the notion of contracting-out but did so in the context of Article 9 generally.

"Mr Bone is free to stay or leave during prayers. It is in accordance with the law. It is not discriminatory, or to the extent that it is, it is justified. I cannot see that his freedom of religion, thought or conscience is infringed by the degree of embarrassment he feels, which is no more than is inherent in the exercise by the others of their freedom to manifest their religious beliefs, and his freedom to stay without participating or to leave. It is their freedom which would be infringed were he right." ${ }^{144}$

This conflation of interference and justification issues can also be found in two recent Court of Appeal decisions. The Court of Appeal decision in Bull \& Bull v Hall \& Predd $y^{145}$ concerned discrimination on grounds of sexual orientation. The religious actors, the Bulls, were the defendants not the claimants. They were hotel owners who preferred to let double accommodation to heterosexual married couples only'

142 Para 34.

143 [2012] EWHC 175 (Admin).

144 Para 72.

145 [2012] EWCA Civ 83. The Supreme Court has given permission for a further appeal in this matter which is likely to be heard in 2013. 
and so turned away a homosexual couple who had entered into a civil partnership. Rafferty LJ held that this constituted direct discrimination on grounds of sexual orientation because a 'homosexual couple cannot comply with the restriction because each party is of the same sex and therefore cannot marry' meaning that 'the criterion at the heart of the restriction, that the couple should be married, is necessarily linked to the characteristic of an heterosexual orientation' and there was therefore less favourable treatment on grounds of sexual orientation. ${ }^{146}$

Moreover, Rafferty LJ held that this conclusion was compatible with Article 9. At first instance, His Honour Judge Rutherford, held that the hotelier's Article 9 rights had been affected. ${ }^{147}$ However, this was justified under Article 9(2) because in so far as the regulations [prohibiting discrimination on grounds of sexual orientation] do affect this right they are ... a necessary and proportionate intervention by the state to protect the rights of others. ${ }^{148}$ At the very least, it can be said that the treatment of Article 9 here is a little cursory. The suggestion once again that the legal requirement not to discriminate on grounds of sexual orientation will automatically justify religious discrimination claims. ${ }^{149}$ However, there seems to be a welcome step away from the Begum precedent in that at least it was accepted that the religious rights were interfered with.

Rafferty LJ made reference to the Article 9 caselaw in her discussion of discrimination:

"The article did not protect hoteliers who claimed that their 'religious beliefs justified their refusal to provide double beds to homosexual couples' as 'the provision of hotel rooms is legal and occurs nowhere other than in an hotel', and the hoteliers could "manifest [their] beliefs in many ways outside the commercial sphere."'150

This would seem to be an application of the contracting-out doctrine in the context of providing an answer to the question of justification under Article 9(2) (as opposed to its usual application in response to the question of interference under Article $9(1)$ ). Whilst many objections concerning the contracting out doctrine continue to apply here, its relevance and applicability under Article 9(2) is preferable to that

146 Para 40.

147 Bristol County Court Case No 9BC02095/6 (4 January 2011).

148 [2012] EWCA Civ 83 at para 39.

149 See also the cases of Ladele and Johns, discussed elsewhere. In the former a judgment in the European Court of Human Rights is awaited following argument on 4 September 2012.

150 Para 48, quoting from Pichon and Sajous v France Application 49853/99 (2 October 2001) but substituting the facts of the instant case. 
under Article 9(1). When the rule is applied under Article 9(1) then the finding is that there has been no interference with Article 9 and so the claim is automatically dismissed. In contrast, where the rule is applied under Article 9(1) then the finding is part of the wider question of justification, allowing the merits of the case to be examined. This would therefore appear to be a step in the right direction.

This approach was also followed in a 'classic' case of where the specific situation rule would be applied. The Court of Appeal in Michael Peter Lyons $v R^{151}$ applied the specific situation rule in respect of a Medical Assistant to the Navy who appealed his conviction for intentionally disobeying a lawful command, inter alia, on the basis that the order contravened his Article 9 rights as a conscientious objector. Toulson LJ held that current arrangements considering conscientious objection had been followed and that this was not in breach of Article 9:

"A person who voluntarily enters military service undertakes serious responsibilities potentially involving the lives and safety of others. If he seeks to be discharged from further service on the ground of conscientious objection, it is right that there should be a proper process for deciding whether his claim is well founded. Until that has been established it is necessary and just that he should continue to be subject to the requirements of military service and military discipline. Otherwise he could immediately escape from the responsibilities which he had voluntarily accepted, regardless of the consequent risk to others and regardless of whether or not his claim was well founded." 152

This is largely uncontroversial. If there is such a rule as the specific situation rule, then it clearly applies on these facts. However, interestingly, the part of the judgment, which examined the Article 9 claim, considered Article 9 as a whole and did not distinguish between the questions of interference and justification. Again, in this case, the specific situation rule appears to be applied as part of the analysis of the Article 9(2) question of justification rather than the Article 9(1) question of interference:

"The fact that a person has volunteered for military service, and so voluntarily accepted the responsibilities which go with such service, may be highly material when considering the balance to be struck between the individual's conscience and the interest of public safety, the protection of 
public order and the protection of the rights of others, to which article 9.2 refers." 153

This is to be welcomed. It represents a move towards focusing more on the question of justification under Article 9(2) rather than dismissing claims under the question of interference under Article 9(1). Michael Peter Lyons is in line with the Strasbourg jurisprudence; so, but to a lesser extent, are Bull \& Bull and Bideford. The United Kingdom judiciary appear to be becoming more comfortable with Article 9(1) and are more willing to consider that Article 9(1) may be engaged. The trend, however, is not all one way. This is shown by the Court of Appeal decision in President of the Methodist Conference $v$ Preston ${ }^{154}$ the latest in a long line of cases concerning whether ministers of religion can be regarded as employees. ${ }^{155}$ In New Testament Church of God v Stewart ${ }^{156}$ the Church appealed against the finding of the Employment Tribunal that a minister of religion whose position as a pastor had been terminated was an employee arguing inter alia, that this decision infringed their Article 9 rights. The Court of Appeal dismissed the appeal but expressed some enthusiasm for the Article 9 claim. Pill LJ held that the law should not readily impose a legal relationship on members of a religious community, which would be contrary to their religious beliefs while Arden LJ held that:

"A religious organisation may, as one of its beliefs, consider that ministers should not have contracts of employment or that the state should not interfere in the way they conduct their organisation. If the state interferes with that belief, there may be an interference with the group's article 9 right (though the interference will not constitute a violation of article 9 if the conditions in article 9(2) are satisfied)."157

153 Para 28.

154 [2011] EWCA Civ 1581.

155 See also J Duddington, 'God, Caesar and the Employment Rights of Ministers of Religion' (2007) 159 Law and Justice 129-135; F Cranmer, 'Clergy Employment, Judicial Review and the Free Presbyterian Church of Scotland' (2010) 12(3) Ecclesiastical Law Journal 355-360; and J Rivers, The Law of Organized Religion(Oxford University Press, Oxford 2010) chapter 4.

156 [2007] EWCA Civ 1004.

157 Para 61. 
In President of the Methodist Conference $v$ Preston ${ }^{158}$, however, Maurice Kay LJ held that Article 9 was not material to the ratio of Stewart. ${ }^{159}$ He held that the 'potential role of Article 9 in cases such as this' was 'far more modest' ${ }^{160}$ and referred to:

"The unattractiveness and moral poverty of the attempted invocation of Article 9 in this case." 161

\section{OTHER CONVENTION RIGHTS}

Several other Articles of the European Convention on Human Rights affect religious individuals. These other Articles are relevant for two main reasons: first, because the ECHR is a living document, Articles must be interpreted in the spirit of the entire Convention. Second, religious claims may be advanced under Articles other than Article 9. Litigants invariably rely on other Articles in addition to Article 9. For instance, registration cases are sometimes argued primarily under Article 11 (peaceful assembly and association) rather than Article 9. In Moscow Branch of the Salvation Army v. Russia ${ }^{162}$ the refusal to grant re-registration to the Moscow Salvation Army on the grounds, inter alia, that it was and in essence ... a quasimilitary religious organisation that has a rigid hierarchy of management' was argued to be a breach of Article 11 read in the light of Article 9. It has been suggested that treating such claims as being primarily concerned with Article 11 is advantageous to Strasbourg since the Court 'has tended to accord a greater degree of scrutiny to the application of restrictions under Article 11(2) than under Article 9(2) ${ }^{\prime}{ }^{163}$ In Church of Scientology Moscow v. Russia ${ }^{164}$ the Court stressed that States 'have only a limited margin of appreciation' under Article 11(2). ${ }^{165}$

158 [2011] EWCA Civ 1581.

159 Para 30.

160 Para 32. He cited Arden LJ and Lawrence Collins LH in Stewart to support this. However, although he claims that Arden LJ 'took a less expansive approach' than Pill LJ, he bases this on the general points outlined by Arden LJ in para 62 of his judgment about the limits of the position in para 61 whilst ignoring the enthusiasm found within para 61.

161 Para 34.

162 [2006] ECtHR (No.72881/01).

163 M.D. Evans, 'Freedom of Religion and the European Convention on Human Rights: Approaches, Trends and Tensions', in Law and Religion in Theoretical and Historical Context, ed. P. Cane et al. (Cambridge: Cambridge University Press, 2008), 291, 310.

164 [2007] ECtHR (No. 18147/02).

165 At para. 86. 
Further, the enjoyment of all Convention rights is subject to Article 14. While Article 9 may be said to be concerned with positive religious freedom (the liberty to believe and manifest one's belief) Article 14 is concerned with negative religious freedom (the liberty from coercion or discrimination on the grounds of belief). ${ }^{166}$ Article 14 forbids discrimination on, inter alia, grounds of religion but only does so in regard to 'the rights and freedoms set forth in this Convention'. Article 1 of Protocol 12 extends this to 'any right set forth by law' but this has not been ratified in the UK.

However, this does not mean that a 'violation of a substantive Article need to be established at all in cases involving discrimination' under Article $14 .{ }^{167}$ Strasbourg has confirmed that 'a measure which in itself is in conformity with the requirements of the Article enshrining the right or freedom in question may however infringe this Article when read in conjunction with Article 14 for the reason that it is of a discriminatory nature, ${ }^{168}$ that is, if the distinction has no objective and reasonable justification. ${ }^{169}$ The Strasbourg court in the pending decision in Church of Jesus Christ of Latter-day Saints v United Kingdom will address this issue. ${ }^{170}$ Other Articles will often interact with Article 9; for instance, where freedom of expression clashes with freedom of religion. Strasbourg has held that the freedom to manifest religion does not include a right to be exempt from all criticism ${ }^{171}$ and freedom of expression contains 'a duty to avoid expressions that are gratuitously offensive to others and profane. ${ }^{\prime} 72$

166 R. Ahdar \& I. Leigh, Religious Freedom in the Liberal State (Oxford: Oxford University Press, 2005), 100.

167 P.M. Taylor, Freedom of Religion (Cambridge: Cambridge University Press, 2005), 182183.

168 Case Relating to Certain Aspects of the Laws on the Use of Languages in Education in Belgium EHRR 1 (1979-80): 252 (at 282).

169 Infringement with Art. 14 may be justified if it pursues a 'legitimate aim' and if there is a 'reasonable relationship of proportionality between the means employed and the aim sought to be realised' (Darby v. Sweden (1991) 13 EHRR 774).

170 Church of Jesus Christ of Latter-day Saints v United Kingdom (App No 7552/09), European Court of Human Rights.

171 İA v. Turkey (Application no. 42571/98) 13 Sep. 2005, para. 28: 'Those who choose to exercise the freedom to manifest their religion, irrespective of whether they do so as members of a religious majority or a minority, cannot reasonably expect to be exempt from all criticism. They must tolerate and accept the denial by others of their religious beliefs and even the propagation by others of doctrines hostile to their faith.'

172 İA v. Turkey (Application no. 42571/98) 13 Sep. 2005, para. 24. 


\section{COLLECTIVE RELIGIOUS FREEDOM}

English law recognises and regulates collective religious freedom in a number of other ways. Religious groups enjoy a number of exceptions from general rules, including those in discrimination law. At first sight, section 13 of the Human Rights Act 1998 seems to accord a special protection for the religious freedom of religious organisations. It reads:

1. If a court's determination of any question arising under this Act might affect the exercise by a religious organisation (itself or its members collectively) of the Convention right to freedom of thought, conscience and religion, it must have particular regard to the importance of that right.

2. In this section 'court' includes a tribunal.

Section 13 was the result of lobbying by religious groups during the passage of the Human Rights Bill through Parliament. The Roman Catholic Church, the Chief Rabbi, the Church of Scotland and the Plymouth Brethren joined Evangelical Christians. ${ }^{173}$ Section 13 was therefore added as 'an attempt to reassure the Churches' about the impact of the Act. ${ }^{174}$ The Government contending that religious groups would not generally be 'public authorities' (and thus susceptible to claims under the Act) with the exception of where they stood in the place of the State providing a public service. ${ }^{175}$

While, by analogy, certain cases on a parallel provision on freedom of expression and the press have hinted that section 13 might give presumptive priority to religious freedom, ${ }^{176}$ it has also been held that section 13 does not allow religious freedom to trump other rights such as Article $6 .{ }^{177}$ In practice, it seems that the section is a dead letter: section 13 hardly features in higher court judgments concerning freedom

173 P. Cumper, 'Religious Organisations and the Human Rights Act 1998', in Law and Religion in Contemporary Society, ed. P.W. Edge \& G. Harvey (Aldershot: Ashgate, 2000), 72.

174 Jack Straw, then Home Secretary, Commons Hansard 20 May 1998: Column 1021.

175 Ibid., Column 1017.

176 Douglas v. Hello! Ltd [2001] QB 967, per Sedley LJ; Lakeside Homes Limited v. BBC [2000] WL 1841602, per Creswell J.

177 The Queen on the Application of Ullah v. Special Adjudicator [2002] EWHC 1584 (Admin) per Harrision J. 
of religion. ${ }^{178}$ Commentators seem agreed that the section is 'rather mild', ${ }^{179}$ largely symbolic $^{180}$ and 'at best an articulation and codification' of the pre-Human Rights Act position. ${ }^{181}$

Notwithstanding the limited effect of section 13, as the text of Article 9 makes clear, the right to manifest religion or belief may be exercised 'either alone or in community with others and in public or private. This means that religious groups enjoy the protections afforded by the Human Rights Act and may bring claims under the Act.

\section{The Strasbourg Approach}

Strasbourg has held that Article 9 permits religious autonomy and diversity in terms of the regulation of religious groups. ${ }^{182}$ Convention organs have accepted a variety of Church-State relations as being part of the contracting State's margin of appreciation. Mild forms of State preference for one religion over another do not violate the ECHR. It was noted in Darby v. Sweden:

"A State Church system cannot in itself be considered to violate Article 9 of the Convention ... however, a State Church system must, in order to satisfy Article 9, include specific safeguards for the individual's freedom of religion." ${ }^{183}$

The Grand Chamber in Refah Partisi v. Turkey ${ }^{184}$ made it clear that States are required to facilitate religious freedom, noting that 'the State's role as the neutral and impartial organiser of the exercise of various religions, faiths and beliefs, $\ldots$ is conducive to public order, religious harmony and tolerance in a democratic society' ${ }^{185}$

178 M, Hill, Ecclesiastical Law, $3^{\text {rd }}$ edn (Oxford: Oxford University Press, 2007), para. 1.47.

179 R. Ahdar \& I. Leigh, Religious Freedom in the Liberal State (Oxford: Oxford University Press, 2005), 359.

180 P. Cumper, 'The Protection of Religious Rights under Section 13 of the Human Rights Act 1998' [2000] PL 265; J. Wadham \& H. Mountfield, Blackstone's Guide to the Human Rights Act 1998 (London: Blackstone, 1998), 55.

181 M. Hill, 'Judicial Approaches to Religious Disputes', in Law and Religion, ed. R. O’Dair \& A. Lewis (Oxford: Oxford University Press, 2001), 419.

182 See R. Ahdar \& I. Leigh, Religious Freedom in the Liberal State (Oxford: Oxford University Press, 2005), 135-138.

183 EHRR 13 (1991): 774.

184 EHRR 37 (2003): 1.

185 Paragraph 91. 
Strasbourg has also accepted claims by religious groups. Under Article 34, the two rules of standing are that the applicant must be a person, a non-governmental organisation or group of individuals and that the applicant must be a victim. While originally Strasbourg maintained a line that religious groups only enjoyed Convention rights as individual rights bestowed on members but not grounded in their own right, ${ }^{186}$ it has since been accepted that this is an artificial distinction and that a religious group is capable of possessing and exercising the rights ... in its own capacity as a representative of its members. ${ }^{187}$ It remains the case, however, that the religious group must be a non-governmental body. The fact that there may be a close affinity between the religious group and the State does not preclude the group from seeking redress in Strasbourg. ${ }^{188}$

\section{United Kingdom law}

Domestic courts have followed Strasbourg in admitting claims by religious groups. In Gallagher (Valuation Officer) v. Church Of Jesus Christ Of Latter-Day Saints ${ }^{189}$ the Church of Jesus Christ of Latter-Day Saints (often known as Mormons) appealed from the ruling of the Court of Appeal ${ }^{190}$ which had held that the Temple and several associated buildings were not entitled to an exemption from non-domestic rates as a 'place of public worship' under paragraph 11 of Schedule 5 to the Local Government Finance Act 1988 since it was open only to those 'Patrons' who had a 'recommend' from the bishop. The House of Lords had already decided in Church of Jesus Christ of Latter-Day Saints v. Henning (Valuation Officer) ${ }^{191}$ that the words 'place of public religious worship' could not apply to a place from which the public was excluded. A human rights argument was raised for the first time at the House of Lords in Gallagher: it was contended that the exclusion from the Temple of all but Patrons was a manifestation of the Mormon faith and to deny the exemption was contrary to Articles 9 and 14.The haste in which the argument was rejected and the lack of sophistication has led to academic criticism. ${ }^{192}$

186 Church of X v. United Kingdom (1968) 29 CD 70.

$187 X$ and the Church of Scientology v. Sweden (1979) 16 DR 68.

188 Holy Monasteries v. Greece (1995) 20 EHRR 1.

189 [2008] UKHL 56.

190 [2006] EWCA Civ 1598.

191 [1964] AC 420.

192 R. Sandberg, 'Underrating Human Rights: Gallagher v. Church of Jesus Christ of the Latter-Days Saints', Ecc LJ 11 (2009): 75-80. 
Lords Hoffmann and Hope held that there was no interference with Articles 9 and 14 since the requirement that in order to constitute discrimination on grounds of religion, the alleged discrimination must fall 'within the ambit' of Article 9 had not been met since there was no breach of Article 9. This rests on a misunderstanding. It is true that Article 14 is not a freestanding discrimination provision in that it only forbids discrimination in regard to 'the rights and freedoms set forth in this Convention'193 (and that this may be styled as saying that that the discrimination must 'fall within the ambit' of another substantive article). However, this does not mean that a 'violation of a substantive Article needs to be established at all in cases involving discrimination' under Article $14 .{ }^{194}$ Strasbourg has confirmed that 'a measure which in itself is in conformity with the requirements of the Article enshrining the right or freedom in question may however infringe this Article when read in conjunction with Article 14 for the reason that it is of a discriminatory nature, ${ }^{195}$ that is, if the distinction has no objective and reasonable justification. Infringement with Article 14 may be justified if it pursues a 'legitimate aim' and if there is a 'reasonable relationship of proportionality between the means employed and the aim sought to be realised.' ${ }^{196}$

The Strasbourg-compliant approach in Gallagher was therefore that taken by Lord Scott who held that there was an interference with Article 14 in conjunction with Article 9 because there did not need to be an actual breach of the substantive Article. However, Lord Scott held that this discrimination was justifiable: States were entitled to conclude that religion was capable of being divisive and since 'secrecy in religious practices provides the soil in which suspicions and unfounded prejudices can take root and grow' there was 'every reason why a state should adopt a general policy under which fiscal relief for premises used for religious worship is available where the premises are open to the general public and is withheld where they are not. ${ }^{197}$

The Human Rights Act 1998 has the potential to be used against religious groups, particularly the established Church of England. If a religious group is regarded as a 'public authority' in the language of the Act then human rights expectations (and

193 Article 1 of Protocol 12 extends this to 'any right set forth by law' but this has not been ratified in the UK.

194 P.M. Taylor, Freedom of Religion (2005, Cambridge University Press) 182-183.

195 Case Relating to Certain Aspects of the Laws on the Use of Languages in Education in Belgium EHRR 1 (1979-80): 252 (at 282).

196 Darby v. Sweden (1991) 13 EHRR 774.

197 Paragraph 51. 
ultimately claims) may be levelled at it. Aston Cantlow v. Wallbank ${ }^{198}$ concerned a Parochial Church Council (PCC) of the Church of England which sought to enforce a liability under the Chancel Repairs Act 1932 against lay rectors to compel them to pay for chancel repairs. The lay rectors contended that the PCC was a 'public authority' for the purposes of the Human Rights Act 1998 and thus could not act in a way incompatible with the Convention rights and that by requiring them to pay interfered with their right to peaceful enjoyment of their possessions under Article 1 of the First Protocol.

The House of Lords held that the PCC was not acting as a public authority for this purpose. A public authority could either be a 'core' public authority that exercised functions that were broadly governmental so that they were all functions of a public nature or a 'hybrid' public authority, which exercised some functions of a public nature. The PCC was not a 'core' public authority since although the Church of England had special links with central government and performed certain public functions, the Church of England generally, and PCCs in particular, were essentially religious rather than governmental organisations. Even if the PCC was a 'hybrid' public authority, enforcement of chancel repair liability was not a function of a public nature; rather it was a private function. Moreover, in any case Article 1 of the First Protocol to the Convention did not protect the appellants, since a person's right to peaceful enjoyment of their possessions does not extend to the grant of relief from liabilities incurred under the civil law. The appellants were not being deprived of their possessions but were merely being required to fulfil an obligation that they had voluntarily assumed.

The case is significant in that the House of Lords focused squarely on the public authority point. The decision means neither the Church of England (in some generic sense) nor its component institutions are 'core' public authorities. ${ }^{199}$ From the decisions of the Law Lords it may be inferred that there is a possibility that human rights may be enforced against components of the Church of England if they are 'hybrid' public authorities fulfilling a public function and that this may occur in certain situations such as marriage. For the most part, however, the established Church and its organs will not be a public authority and it is unlikely that other religious groups and their institutions will be so regarded. Indeed, Lord Nicholls saw section 13 of the Human Rights Act 1998 as providing that religious organisations

198 [2003] UKHL 37.

199 Lord Nicholls held that to hold that PCCs are core public authorities and are not capable of being victims would be 'an extraordinary conclusion': para. 15. 
enjoyed Article 9 rights and that it would be expected that the Church of England would enjoy this and other Convention rights as much as other religious bodies.

In the case of Percy, ${ }^{200}$ Lord President Rodger took a similar line, obiter, in relation to the Church of Scotland as was later adopted by the House of Lords for the Church of England. ${ }^{201}$ He treated the Church of Scotland simply as a voluntary organisation, stating that although the laws of the Church and the procedures of the Church courts had much in common with Scots law generally, this merely revealed the hand which those trained in Scots law have had in guiding such proceedings down the centuries'. Despite this, 'the laws of the Church operate only within the Church and her courts adjudicate only on matters spiritual. In other words, the formality and indeed solemnity of all these transactions and proceedings does not disclose an intention to create relationships under the civil law; rather, it reflects the serious way in which the Church regulates the matters falling within the spiritual sphere. ${ }^{202}$

For the purposes of the new legal landscape under the Human Rights Act 1998, consideration must be given as to which component part or parts, if any, of the Church of England and the Church of Scotland are to be classified 'public authorities' and thus under a duty to act in accordance with the provisions of the European Convention on Human Rights. Two specific possibilities are the General Synod of the Church of England and the General Assembly of the Church of Scotland. As to the former, the General Synod exercises a public function by way of its power to amend statute law: for example, the Worship and Doctrine Measure 1974 repealed what was left of the Act of Uniformity 1662. As to the latter, Lord President in Percy did not specifically address the constitutional status of the General Assembly itself. Given that the General Assembly exercises a separate jurisdiction ${ }^{203}$ in parallel with those of the Court of Session and the High Court of Justiciary, it is arguable that it is a public authority, even if those functions are nowadays somewhat attenuated. It

200 Helen Percy v. An Order and Judgment of the Employment Appeal tribunal dated 22 Mar. 199920 Mar. 2001 Inner House 057/17/99.

201 Aston Cantlow v. Wallbank [2003] UKHL 37.

202 At para. 14.

203 See, e.g., Lord Justice Clerk Moncreiff in Wight v. Presbytery of Dunkeld (1870) 8 M 921 at 925: 'The jurisdiction of the Church courts, as recognised judicatories of this realm, rests on a similar statutory foundation to that under which we administer justice within these walls ... Within their spiritual province the Church courts are as supreme as we are within the civil' and Lord Osborne in Logan v. Presbytery of Dumbarton 1995 SLT 1228: it seems to me that the situation of the courts of the Church of Scotland cannot be equiparated with any tribunal created or upon which a power has been conferred by Parliament'. 
is possible, therefore, that both the General Synod and the General Assembly might reasonably be regarded as hybrid authorities: thus bound by Convention rights whenever exercising a public function.

In $R$ (Baiai and others) $v$. The Secretary of State for the Home Department and others, ${ }^{204}$ the issue was whether a scheme under the Asylum and Immigration (Treatment of Claimants, etc.) Act 2004, which prescribed that any person who was subject to immigration control and wished to enter into a civil marriage in the United Kingdom had to apply to the Secretary of State for a certificate of approval to marry, though lawful in concept, was implemented through overly rigid governmental guidance which breached the right to marry under Article 12 ECHR. A judge of the High Court ${ }^{205}$ had held that that the reference to 'civil marriage' under the Act was discriminatory since it exempted from the certificate of approval process those who married according to the rites of the Church of England. This, he concluded, violated Article 14 on the grounds that it was discriminatory. An appeal on this finding was not pursued by the Secretary of State in the Court of Appeal ${ }^{206}$ and did not fall for consideration in the House of Lords. ${ }^{207}$ Nonetheless, certain Law Lords made some surprisingly ill-informed comment on the legal status of Anglican marriage. ${ }^{208}$ Although the Secretary of State had undertaken before the Court of Appeal to remove the discriminatory aspects of the Scheme, a government circular, issued on 13 November 2009, conceded that the United Kingdom Borders Agency could not find a workable system, which did not discriminate between civil and Anglican marriages. ${ }^{209}$ The legal landscape has changed further in recent years with the introduction of civil partnerships, their subsequent registration on religious premises, and the current Government proposals on same-sex marriage.

204 At first instance before Silber J, initially at [2006] EWHC 823 but with two subsequent first instance judgments, and in the House of Lords [2008] UKHL 53.

205 [2006] EWHC (Admin) 823.

206 [2007] EWCA Civ 478.

207 [2008] UKHL 53.

208 Discussed by M Hill in an Editorial comment in the Ecclesiastical Law Journal at (2009) Ecc LJ 11.

209 GRO Circular 9/2009. 
